\title{
Stabilizing Na-bentonite by Poly(Diallyl Dimethyl Ammonium Chloride) Adsorption
}

\author{
Mohamed. A. ABDEL-KHALEK ${ }^{1)}$, Ayman. A. EL-MIDANY')
}

\author{
${ }^{1)}$ Central Metallurgical R\&D Institute (CMRDI), Helwan, Egypt \\ 2) Mining, Petroleum, and Metallurgy Dept., Cairo University, Cairo, Egypt; email: aelmidany@eng.cu.edu.eg, tel.:+20 2 35678526; fax: \\ $+20235723486$
}

http://doi.org/10.29227/IM-2021-01-11

Submission date: 12-01-2021 | Review date: 16-05-2021

\section{Abstract}

Clay minerals have been modified by polymers for different applications. The polymer addition affects not only the surface properties but also the rheological properties and the stability of the clay-polymer suspension as a whole. In the current study, the electro-chemical properties of bentonite particles in presence of poly diallyl dimethyl ammonium chloride (PDDACl) were investigated. These properties were characterized by as zeta potential, adsorption isotherm, Fourier transform infrared (FTIR) and the apparent viscosity at different solid percent. The results indicated that the viscosity of the bentonite-PDDACl suspension not only increases by raising the polymer concentration but also by increasing solids \%. Adsorption of PDDACl polymer increases the positivity of bentonite surface as a function of polymer concentration, which could be explained mainly by electrostatic interaction of deficient metal ions at the octahedral sheets of bentonite with the cationic head group of the polymer. The PDDACl adsorption isotherm on bentonite fits more probably Langmuir than Freundlich isotherm.

Keywords: bentonite, clay, cationic polymer, Poly(diallyl dimethyl ammonium chloride), viscosity

\section{Introduction}

Most of the industrial applications of clay minerals depend on the adsorption of polymers on clay raw material [13]. The clay- polymers interactions modify the physico-chemical properties of the clay particles. Surface charge, surface active sites and functional groups, rheology and suspension dispersibility are the most important for industrial and technological prospective [4-5]. Several types of polymers of different ionic characters and even non-ionic polymers were applied to modify the clay suspension properties [6-7]. The electrokinetic and rheological properties of different types of clays in presence of salts, surfactants and polymers are the subject of various studies [8-12].

The interaction of polymer functional groups to clay surface significantly affects the interfacial and flow characteristics of the clay-polymer suspension. A great number of studies focused on the adsorption of polymers on kaolinite, which has 1:1 layer structure with low exchange capacity and minimal layer charge. On the other hand, the montmorillonite, smectite group, attract more attention due to its 2:1 layer structure with high exchange capacity and high layer charge [13-16].

Treating the montmorillonite with cationic polymers is one of the promising techniques not only to control the surface charge but also its reversal as well as changing its rheological properties. However, the cationic polymer effect depends mainly on the intrinsic polymer characteristics such as molecular weight and its function groups. Poly (diallyl dimethyl ammonium chloride) is one of widely used cationic polymers in the industry. For instance, the adsorption of Poly (diallyl dimethyl ammonium chloride) onto kaolinite and its effect on its electrokinetic and rheological properties was investigated [17].
Therefore, the aim of the current study is investigating the adsorption of Poly (diallyl dimethyl ammonium chloride) onto bentonite, as a different structure from kaolinite, was investigated using adsorption, Fourier Transform Infra-Red (FTIR), apparent viscosity and electro-kinetic (zeta potential) measurements. The effect of such bentonite-polymer interaction on the suspension stability in terms of electrical and rheological properties was discussed. In addition, the adsorption trend was fitted to Langmuir and Freundlich isotherms and the adsorption mechanism was highlighted.

\section{Experimental \\ 2.1. Materials \\ 2.1.1. Clay}

The bentonite sample was kindly provided by "Egypt bentonite and derivatives Co.", Western Desert, Egypt. The selection of this locality was mainly because of the presence of high proportion of montmorillonite with the lowest amount of impurities.

\subsubsection{Polymer}

Poly (diallyldimethylammonium chloride), (C8H16ClN) $\mathrm{n}$, was obtained from Sigma-Aldrich Co. (USA) with average molecular weight ( $\mathrm{Mw} \sim 100,000-200,000)$, Figure 1 . The polymer solution was prepared at $3 \%$ in bi-distilled water. The reagent grade $\mathrm{HCl}$ and $\mathrm{NaOH}$ were used as $\mathrm{pH}$ modifiers.

\subsection{Methods}

\subsubsection{Viscosity Measurements}

Bentonite suspensions of $(4-10 \% \mathrm{w} / \mathrm{w})$ were prepared in de-ionized water as well as with different polymer concentrations $(0,20$ and $60 \mathrm{mg} / \mathrm{l})$ at constant temperature $(25.0 \pm$ $0.5^{\circ} \mathrm{C}$ ) after $24 \mathrm{~h}$ of mixing at $600 \mathrm{rpm}$ to determine the sus- 
Tab. 1. Chemical analysis of the bentonite sample

Tab. 1. Analiza chemiczna próbki bentonitu

\begin{tabular}{|l|c|}
\hline \multicolumn{1}{|c|}{ Component } & $\%$ \\
\hline $\mathrm{SiO}_{2}$ & 52.49 \\
$\mathrm{Al}_{2} \mathrm{O}_{3}$ & 21.58 \\
$\mathrm{Fe}_{2} \mathrm{O}_{3}$ & 10.82 \\
$\mathrm{TiO}_{2}$ & 1.56 \\
$\mathrm{CaO}$ & 0.42 \\
$\mathrm{MgO}$ & 3.21 \\
$\mathrm{Na}_{2} \mathrm{O}$ & 0.84 \\
$\mathrm{~K}_{2} \mathrm{O}$ & 0.41 \\
$\mathrm{P}_{2} \mathrm{O}_{5}$ & 0.09 \\
Ignition loss & 8.56 \\
\hline Total & 99.98 \\
\hline
\end{tabular}

Tab. 2. Size distribution of bentonite sample Tab. 2. Rozkład wielkości próbki bentonitu

\begin{tabular}{|c|c|}
\hline Particle size, $\mu \mathrm{m}$ & $\%$ Retained \\
\hline+100 & 0.12 \\
$-100+74$ & 2.56 \\
$-74+53$ & 38.18 \\
$-53+45$ & 36.89 \\
$-45+32$ & 16.94 \\
$-32+20$ & 3.76 \\
$-20+10$ & 0.98 \\
-10 & 0.57 \\
\hline
\end{tabular}

Tab. 3. Isotherms model constants and correlation coefficient (R2)

Tab. 3. Stałe modelu izoterm i współczynnik korelacji (R2)

\begin{tabular}{|c|c|c|c|}
\hline Isotherm model & \multicolumn{3}{|c|}{ Isotherm constants } \\
\hline \multirow{2}{*}{ Langmuir } & $\mathrm{q}_{\max }$ & $\mathrm{b}$ & $\mathrm{R}^{2}$ \\
\cline { 2 - 4 } & 1.1223 & 0.1828 & 1.00 \\
\hline \multirow{2}{*}{ Freundlich } & $\mathrm{K}_{\mathrm{f}}$ & $\mathrm{N}$ & $\mathrm{R}^{2}$ \\
\cline { 2 - 4 } & 42.10 & 0.51 & 0.9747 \\
\hline
\end{tabular}

pension apparent viscosity. The apparent viscosity, in centipoise, was determined by a Capillary Rheometry Units RH-10 (Malvern Instruments CO., USA) and calculated by dividing rotational viscosity at $600 \mathrm{rpm}$ (R600) by 2 .

\subsubsection{Zeta Potential Measurements}

The zeta potential measurements of bentonite were performed in absence and presence of polymer using a " $\mathrm{Ze}$ ta-meter system 3+ unit (Zeta-meter Inc., USA). A bentonite sample of $0.1 \mathrm{~g}$ was added to $50 \mathrm{ml}$ of definite electrolyte concentration at ionic strength of $10^{-2} \mathrm{M} \mathrm{NaCl}$. The $\mathrm{pH}$ was adjusted to the required value with either $\mathrm{NaOH}$ or $\mathrm{HCl}$ solutions. In the case of using polymer, the required polymer concentrations were added. The suspension was shaken for 30 min then it was transferred to zeta-meter for measurement. Five measurements was taken and averaged to represent the zeta potential at certain $\mathrm{pH}$.

\subsubsection{Adsorption Measurements}

Experiments were carried out using $0.5 \mathrm{~g}$ bentonite in $100 \mathrm{ml}$ of cationic polymer solutions ranging in equilibrium concentration from 0 to $20 \mathrm{mg} / \mathrm{L}$. Solutions were shaken for $8 \mathrm{~h}$ at $25^{\circ} \mathrm{C}$. After centrifugation at $7500 \mathrm{rpm}$ for 20 minutes, decanted solutions were filtered from a $0.45-\mu \mathrm{m}$ membrane filter. The total organic carbon content (TOC) in the supernatant was determined using a "Phoenix 8000" Total Carbon Analyzer (Teledyne Instruments - Tekmar, USA).

\subsubsection{FTIR Measurements}

The FTIR spectra of clay and clay-polymer interactions were recorded by FTIR spectrophotometer (FTLA 2000 Model) using potassium bromide $(\mathrm{KBr})$ disk method in the range of $400-4000 \mathrm{~cm}-1$ at a resolution of $2 \mathrm{~cm}^{-1}$. The FTIR spectra of Poly (diallyl dimethyl ammonium chloride), PDDACl, were examined using FTIR-ATR spectrometer (Scimatar-1000, Varian Associates Inc., USA).

\section{Results and Discussion}

\subsection{Characterization of Bentonite Clay}

Table 1 shows the chemical analysis of the used bentonite sample. The $\mathrm{Al}_{2} \mathrm{O}_{3} / \mathrm{SiO}_{2}$ ratio and the ratio of $\mathrm{Na}_{2} \mathrm{O} / \mathrm{CaO}$, from Table 1, reveal that the sample is Na-bentonite rather than Ca-bentonite [18-19]. The reasonably high loss-on-ignition (L.O.I) value $(>8 \%)$ indicates the higher montmorillonite content. In addition, Table 2 shows the size distribution of the bentonite sample where about $60 \%$ of the sample is $-53 \mu \mathrm{m}$.

\subsection{Zeta Potential}

The change in zeta potential of Na-bentonite as a function of $\mathrm{pH}$ in the absence and the presence of PDDACl is presented in Fig.2. The iso-electric point (iep) of Na-bentonite before the addition of $\mathrm{PDDACl}$ seems to be at highly acidic $\mathrm{pH}$ (between $\mathrm{pH}$ value 1 and 2, not shown in the figure) which coincides with iep values reported for similar clays [20]. After adding $\mathrm{PDDACl}$, as a cationic polymer, the zeta potential moves to the positive potential values. The zeta potential of polymer treated Na-bentonite slightly decreases with increasing $\mathrm{pH}$ values. The most important observation is the shift of iep of the Na- bentonite after adding the polymer.

In addition, changing the polymer concentration at $\mathrm{pH} 7$ was studied, Fig.3. It is noticed that increasing the polymer concentration shifts the zeta potential from negative value $(-36 \mathrm{mV})$ at no polymer additions to positive value $(10 \mathrm{mV})$ at $10 \mathrm{mg} / \mathrm{L}$ polymer concentration. At polymer concentra- 
Tab. 4. The characteristic peaks for bentonite and PDDAC polymer

Tab. 4. Charakterystyczne piki dla bentonitu i polimeru PDDAC

\begin{tabular}{|c|c|c|c|}
\hline Material & $\begin{array}{l}\text { Peaks wave number, } \\
\mathrm{cm}^{-1}\end{array}$ & Description & References \\
\hline Bentonite & $\begin{array}{l}3630 \\
3443 \\
3200-3500 \\
1640 \\
1035 \\
916-\text { and } 626 \\
915 \text { and } 843 \\
519 \text { and } 466\end{array}$ & $\begin{array}{l}\mathrm{O}-\mathrm{H} \text { stretching } \\
\text { interlayer and intralayer } \mathrm{H} \text {-bonded } \mathrm{O}-\mathrm{H} \\
\mathrm{Si}-\mathrm{O} \text { and } \mathrm{Al}-\mathrm{O} \\
\mathrm{H}-\mathrm{O}-\mathrm{H} \text { bending } \\
\mathrm{Si}-\mathrm{O} \text { stretching } \\
\mathrm{Al}-\mathrm{OH} \text { vibration } \\
\mathrm{Al}-\mathrm{O} \text { stretching } \\
\mathrm{Si}-\mathrm{O}-\mathrm{Al} \text { modes }\end{array}$ & {$[23-24]$} \\
\hline $\begin{array}{l}\text { PDDAC } \\
\text { Polymer }\end{array}$ & $\begin{array}{l}3742 \\
2992 \text { and } 1541 \\
2920 \text { and } 1397 \\
1692 \\
1653 \\
1147 \text { and } 1057 \\
679\end{array}$ & $\begin{array}{l}\mathrm{O}-\mathrm{H} \text { stretching } \\
\text { stretching and bending vibrations of methyl } \\
\text { stretching and bending vibrations of methylene } \\
\text { vibration of quaternary ammonium group } \\
\mathrm{OH} \text { bending vibration of water } \\
\text { skeletal vibration mode of } \mathrm{C}-\mathrm{C} \text { groups } \\
\text { rocking mode of } \mathrm{CH}_{2} \text { groups }\end{array}$ & [25] \\
\hline
\end{tabular}<smiles>CN1CC(CC(C)(C)C)C(CC(C)(C)C)C1</smiles>

Tab. 4. The characteristic peaks for bentonite and PDDAC polymer Tab. 4. Charakterystyczne piki dla bentonitu i polimeru PDDAC

tion between $10 \mathrm{mg} / \mathrm{L}$ and $60 \mathrm{mg} / \mathrm{L}$, the zeta potential increases gradually until it reaches a constant value (about 70 $\mathrm{mV}$ ). Achieving a constant potential may be attributed to the balance between positive charges of polymer molecules and negative charges on the bentonite surface, which indicates the electrostatic nature of polymer adsorption. In addition, such balance indicates the formation of polymer monolayer at the bentonite surface, which suggest the Langmuir type of adsorption.

\subsection{Apparent Viscosity}

Addition of solid particles to fluid affects the suspension viscosity due to the interaction between solid particles and fluid molecules, which consequently obstruct the flow and its velocity gradient [21]. Keeping the shear-force constant, the viscosity increases with increasing the solid content as shown in Fig.4. It is clear that increasing the solid content increases the apparent viscosity due to increasing the volume occupied by the solid particles as can be indicated by Einstein's equation, eqn (1) [22]:

$$
\mu_{\mathrm{r}}=1+2.5 \varphi \mu_{\mathrm{r}}=1+2.5 \varphi
$$

or even modified equation proposed by Guth and Simha, eqn (2) [23]

$$
\mu_{\mathrm{r}}=1+2.5 \varphi+14.1 \varphi \mu_{\mathrm{r}}=1+2.5 \varphi+14.1 \varphi^{2}
$$

Where,

$\mu_{\mathrm{r}} \mu_{\mathrm{r}}$ : is the relative viscosity (dimensionless), $\varphi \varphi$ : solid volume fraction.

It is also worth mentioning that the increase in viscosity with increasing both of solid content and polymer dosage reveals the polymer role in dispersing the solid particles by electrostatic repulsion between the particles as confirmed by zeta potential.

\subsection{FTIR}

Figure 5 shows the bentonite characteristic peaks before and after using PDDAC. The main peaks for bentonite and polymer are listed in Table 4 . The FTIR spectra show that the position of $\mathrm{OH}$ groups on bentonite surface does not show significant change after the bentonite - polymer molecules interaction. In addition, the adsorbed water molecules onto bentonite peaks at 3453 and $1642 \mathrm{~cm}^{-1}$ insignificantly shifted to 3441 and $1648 \mathrm{~cm}^{-1}$ for bentonite-PDDACl system, respectively. Conclusively, the bentonite spectra after treatment with polymer is the summation of the individual peaks for bentonite and polymer which indicates the physical interaction, mainly by electrostatic interaction, between them. [17].

\subsection{Adsorption Isotherm}

Figure 6 shows the adsorption isotherm of PDDACl onto bentonite at room temperature $\left(25^{\circ} \mathrm{C}\right)$ and $\mathrm{pH}$ 7. The adsorption isotherm of PDDACl onto Na-bentonite shows a gradual increase in the adsorption density with concentration. The shape of the adsorption isotherm indicates the physical adsorption through following the L-type isotherm in which the slope decreases with increasing the polymer concentration due to the limited vacant adsorption sites [26].

The presence of multivalent cations such as $\mathrm{Ca}$ and $\mathrm{Mg}$ ions in the structure of bentonite, as substitution to $\mathrm{Si}$ and $\mathrm{Al}$ ions in tetrahedral siloxane sheets and octahedral alumina sheet, results in reducing the net positive charge or increases the negative charge [27]. Taking into account that the PDDA$\mathrm{Cl}$ is cationic polymer therefore, it will be electrostatically attracted to surface negative charge on the bentonite particles, where the adsorption depends on simultaneous interaction between cations in the polymer and the anions on the bentonite surface [28-29].

Therefore, Fig. 6 reveals that the adsorption of PDDACl as a cationic polymer starts initially due to electrostatic attraction and the adsorption intensity increases by increasing 


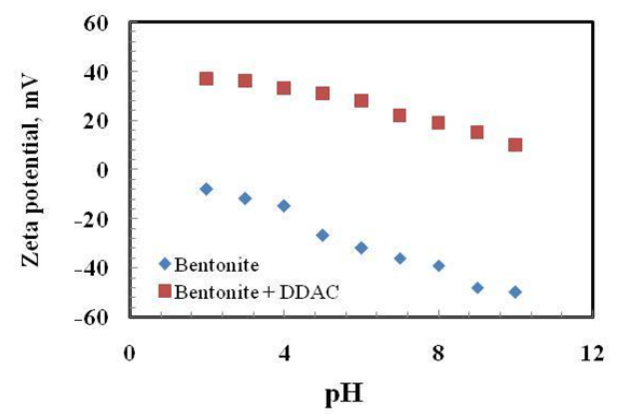

Fig. 2. Zeta potential of bentonite before and after adsorption of polymer in $0.01 \mathrm{M} \mathrm{NaCl}$ solution (at $10 \mathrm{mg} / \mathrm{L}$ polymer concentration) Rys. 2. Potencjał Zeta bentonitu przed i po adsorpcji polimeru w 0,01 M roztworze $\mathrm{NaCl}$ (przy stężeniu polimeru $10 \mathrm{mg} / \mathrm{L}$ )

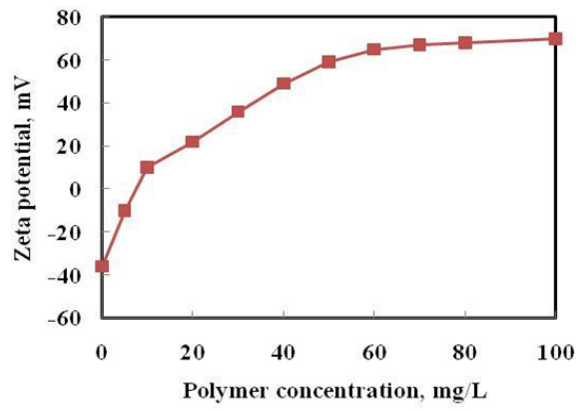

Fig. 3. Zeta potential of bentonite in presence of polymer in $0.01 \mathrm{M} \mathrm{NaCl}$ solution at $\mathrm{pH} 7$ Rys. 3. Potencjał Zeta bentonitu w obecności polimeru w 0,01 M roztworze $\mathrm{NaCl}$ przy pH 7

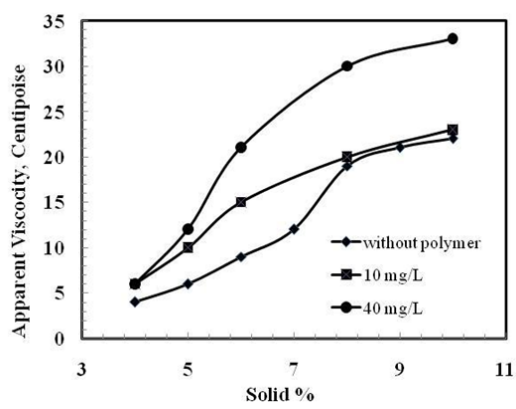

Fig. 4 Effect of polymer additions on the apparent viscosity of bentonite clay at different solid content Rys. 4. Wpływ dodatków polimerowych na lepkość pozorną glinki bentonitowej przy różnej zawartości części stałych

the polymer concentration due to the high cation exchange capacity of montmorillonite.

In addition, the polymer-/bentonite interaction was analyzed by Langmuir and Freundlich isotherms as shown in Figs. 7 and 8, respectively. These isotherms have been frequently used to identify the adsorption behaviour of bentonite and other materials [30-31]. The linear forms of both adsorption isotherm models are given by the equations 1 and 2 :

$$
\begin{array}{ll}
\text { Langmuir } & \mathrm{Ce} / \mathrm{q}=\mathrm{Ce} / \mathrm{K}_{1}+1 / \mathrm{K}_{1} \mathrm{~K}_{2} \\
\text { Freundlich } & \log \mathrm{q}=\log \mathrm{K}_{\mathrm{f}}+\mathrm{N} \log \mathrm{C}
\end{array}
$$

where, $\mathrm{Ce}(\mathrm{mg} / \mathrm{L})$ is the equilibrium concentration of polymer, $\mathrm{q}(\mathrm{mg} / \mathrm{g})$ is the adsorbed amount per unit mass of bentonite, $\mathrm{K}_{1}(\mathrm{mg} / \mathrm{g})$ indicates the maximum adsorption capacity of the polymer onto clay, and $\mathrm{K}_{2}(\mathrm{~L} / \mathrm{mg})$ is an index of adsorption energy. $\mathrm{K}_{\mathrm{f}}(\mathrm{L} / \mathrm{kg})$ and $\mathrm{N}$ denote the monolayer sorp- tion capacity and sorption constant, respectively. In addition, Table 3 shows the isotherms constants and their correlation coefficient. It is clear from Figs. 7 and 8 that the PDDACl on bentonite follow the Langmuir (monolayer) adsorption mechanism.

\section{Conclusions}

Adsorption of PDDACl onto bentonite clay was studied. Adsorption isotherm, zeta potential, FTIR and apparent viscosity measurements were used to clarify the adsorption mechanism. The characterization of clay sample indicated that the sample is Na-bentonite with mean size of $50 \mathrm{mi}$ crons. The results of adsorption isotherm, zeta potential and viscosity, as a function of solid content, indicated that the adsorption of polymer depends mainly on the electrostatic interaction where the positive functional groups of the polymer attach to the negative bentonite surface. In addition, the 


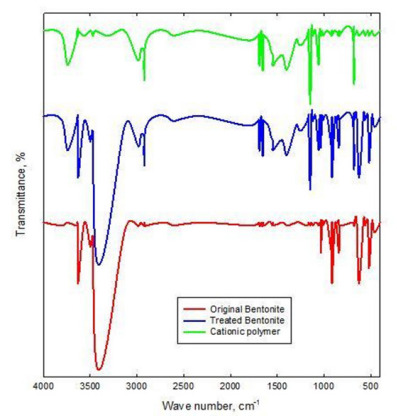

Fig. 5. FTIR spectrum of bentonite, cationic polymer and treated bentonite Rys. 5. Widmo FTIR bentonitu, polimeru kationowego i bentonitu poddanego obróbce

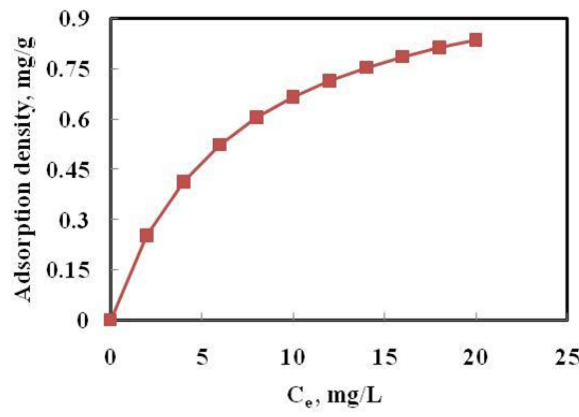

Fig. 6. The adsorption isotherm of cationic polymer on bentonite at $\mathrm{pH}$ Rys. 6. Izoterma adsorpcji polimeru kationowego na bentonicie przy $\mathrm{pH}$

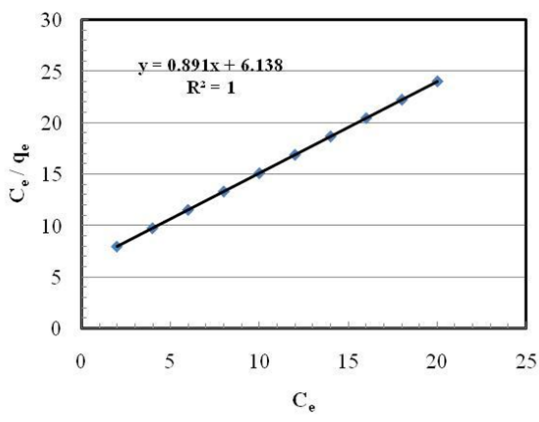

Fig. 7. Langmuir isotherm for polymer adsorption on bentonite Rys. 7. Izoterma Langmuira dla adsorpcji polimeru na bentonicie

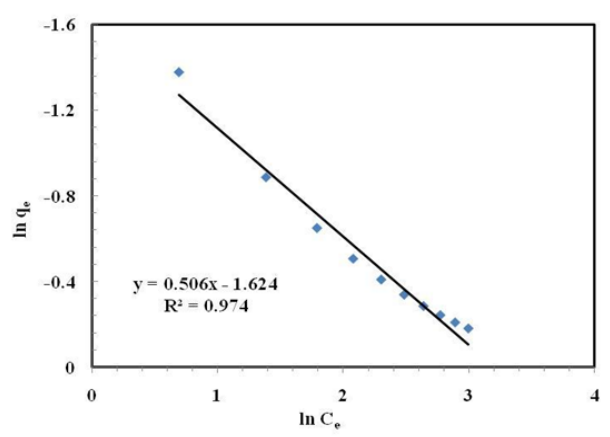

Fig. 8. Freundlich isotherm for polymer adsorption on bentonite Rys. 8. Izoterma Freundlicha dla adsorpcji polimeru na bentonicie

increase in the viscosity with increasing the solid content reveals the role of the polymer in dispersing the solid particles into the liquid phase, which confirms the electrostatic repulsion between bentonite particles especially in the presence of polymer. Such bentonite-polymer interaction modifies the bentonite slurry rheological properties to be suitable for its usage as a drilling mud. In addition, controlling the charge on the bentonite particles by adding the polymer results in its usage in mining industry, paper industry as well as the waste water dewatering. 


\section{Literatura - References}

1. Marco P. and Llorens J., Adsorption of some linear copolymers onto kaolin particles in concentrated suspensions, Colloids Surf. A 270-271 (2005) 291-295. DOI:10.1016/j.colsurfa.2005.06.043.

2. Tunc S., Duman O. and Uysal R., J. Electrokinetic and rheological behaviors of sepiolite suspensions in the presence of poly(acrylic acid sodium salt), polyacrylamides, and poly(ethylene glycol)s of different molecular weights, J. Appl. Polym. Sci. 109 (2008) 1850-1860. DOI: 10.1002/app.28245

3. Kwan C.C., Chiu W.H., Chang N.F., Wu P.S. and Huang K.F., Effect of taurate surfactant and polyvinylpyrrolidone on kaolinite suspension, Colloids Surf. A 377 (2011) 175-181. doi:10.1016/j.colsurfa.2010.12.039

4. Darley, H. C. H. and Gray, G. R., Composition and Properties of Drilling and Completion Fluids, 5th ed.; Gulf: Houston, TX, 1991.

5. Theng, B. K. G. Formation and Properties of Clay-Polymer Complexes; Elsevier Science: Amsterdam, 1979.

6. Luckham P.F. and S. Rossi, The colloidal and rheological properties of bentonite suspensions, Adv. Colloid Interface Sci. 82 (1999) 43-92. doi:10.1016/S0001-8686(99)00005-6

7. Günister E., Study on the effect of BDTDACl and DTABr cationic surfactants on the particle interactions in the Na-activated bentonite-water system by using rheological and electrokinetic methods, B.S. thesis, ITU, Institute of Science and Technology, 2003.

8. Kong H.J., Bike S.G. and Li V.C., Effects of a strong polyelectrolyte on the rheological properties of concentrated suspensions, Cement Concrete Res. 36 (2006) 851-857. doi:10.1016/j.cemconres.2006.02.006

9. Alkan M., Demirbas O. and Dog an M., Electrokinetic properties of kaolinite in mono- and multivalent electrolyte solutions, Micropor. Mesopor. Mat. 83 (2005) 51-59. doi:10.1016/j.micromeso.2005.03.011

10. Niriella D. and Carnahan R.P.: Comparison study of zeta potential values of bentonite in salt solutions, J. Disper. Sci. Technol. 27 (2006) 123-131. Doi:10.1081/DIS-200066860

11. Janek M. and Lagaly G.: Interaction of a cationic surfactant with bentonite: a colloid chemistry study, Colloid Polym. Sci. 281 (2003) 293- 301. Doi:10.1007/s00396-002-0759-Z

12. Clifton M., Nguyen T. and Frost R.: Effect of ionic surfactants on bauxite residues suspensions viscosity, J. Colloid Interface Sci. 307 (2007) 572-577. doi:10.1016/j.jcis.2006.11.058

13. Grim R.E.: Clay Mineralogy, McGraw Hill, New York, 1968.

14. Brindley G.W. and Brown G.: Crystal Structures of Clay Minerals and their X-Ray Identification, Miner. Soc., London, 1980.

15. Murray H.H.: Traditional and new applications for kaolin, smectite, and palygorskite: a general overview, Applied Clay Sci., 17 (2000) 207-221. doi:10.1016/S0169-1317(00)00016-8

16. Celik M. S.: Electrokinetic behavior of clay surfaces, in Clay Surfaces: Fundamentals and Applications, F. Wypych and K. G. Satyanarayana (editors), Elsevier Ltd., 2004.

17. Dumana O., Tunc S. and Cetinkaya A.: Electrokinetic and rheological properties of kaolinite in poly(diallyldimethylammonium chloride), poly(sodium 4-styrene sulfonate) and poly(vinyl alcohol) solutions, Colloids and Surfaces A: Physicochem. Eng. Aspects 394 (2012) 23- 32. doi:10.1016/j.colsurfa.2011.11.018

18. Okwara, C.A. and Osoka, E.C.: Caustic Activation of Local Clays for Palm Oil Bleaching, J. Eng.Applied.Sci, 1(4) (2006)526-52.

19. Veblen, D.R., Guthrie, G.D., Livi, K. J. T. and Reynolds R. C.: High-resolution transmission electron microscopy and electron diffraction of mixed-layer illite/smectite: Experimental results. Clays and Clay Minerals, 38(1990) 1-13. doi:/10.1346/CCMN.1990.0380101

20. Tunc S. and Duman O.: The effect of different molecular weight of poly(ethylene glycol) on the electrokinetic and rheological properties of Na-bentonite suspensions, Colloid Surf. A 317 (2008) 93-99. doi:10.1016/j.colsurfa.2007.09.039

21. Kissa E.: Dispersions - Characterization, Testing, and Measurement, Chp 14 - rheology, 1999, pp 603-694.

22. Einstein, A.: Eine neue Bestimmung der Moleküldimensionen. Annalen der Physik, 19 (1906) 289.

23. Marel, H. W.: Beutelspacher, H. Atlas of infrared spectroscopy of clay minerals and their mixtures. Amsterdam: Elsevier Scientific. (1976).

24. Yang J.C., Jablonsky M.J., and Mays J.W.: NMR and FT-IR studies of sulfonated styrene-based homopolymers and copolymers, Polymer 43 (2002) 5125-5132.

25. doi:10.1016/S0032-3861(02)00390-7 
26. Lu J., Wang X. and Xiao C.: Preparation and characterization of konjac glucomannan/ poly(diallydimethylammonium chloride) antibacterial blend film, Carbohydr. Polym. 73 (2003) 427-437. doi:/10.1016/j.carbpol.2007.12.021

27. Theng B.K.G.: Polymer Behaviour at Clay and Solid Surfaces, chp.2 in Developments in Clay Science, 4(2012) 4775. http://dx.doi.org/10.1016/B978-0-444-53354-8.00002-5

28. Nosrati, A., Addai-Mensah, J. and Skinner, W.: Rheological behaviour of muscovite clay dispersions: effect of water quality and solution speciation. Int. J.Miner. Process, 102-103(2012) 89-98. doi:10.1016/j.minpro.2011.09.009

29. Khan S.A., Rehman R. and Alikhan M.: Adsorption of chromium (III), chromium (VI) and silver (I) on bentonite, Waste Manage. 14 (1995) 271-282. doi:10.1016/0956-053X(95)00025-U

30. Li Q., Yue Q.-Y., Su Y., Gao B.-Y. and Fu L. J.: Cationic polyelectrolyte/bentonite prepared by ultrasonic technique and its use as adsorbent for Reactive Blue K-GL dye, J. Hazard. Mater. 147 (2007) 370-380. doi:10.1016/j. jhazmat.2007.01.024

31. Blachier C., Michot L., Bihannic I., Barrès O., Jacquet A. and Mosquet M. : Adsorption of polyamine on clay minerals, J. Colloid Interface Sci., 336 (2009) 599-606. doi:10.1016/j.jcis.2009.04.021

32. Reed E. and Maasumote K.: Modeling Cadmium Adsorption by Activated Carbon Using the Langmuir and Freundlich Isotherm Expressions, Sep. Sci. Technol. 28 (1993) 2179-2195. Doi:10.1080/01496399308016742

\section{Stabilizacja Na-bentonitu przez adsorpcje poli (chlorku diallilodimetyloamoniowego)}

Minerały ilaste zostały zmodyfikowane przez dodatek polimerów do różnych zastosowań. Dodatek polimeru wpływa nie tylko na właściwości powierzchni, ale również na właściwości reologiczne i stabilność zawiesiny glina-polimer jako całości. W niniejszej pracy zbadano właściwości elektrochemiczne cząstek bentonitu w obecności chlorku polidiallilodimetyloamoniowego (PD$\mathrm{DACl}$ ). Właściwości te scharakteryzowano jako potencjał zeta, izotermę adsorpcji, podczerwień z transformacją Fouriera (FTIR) oraz lepkość pozorną przy różnych zawartościach fazy stałej. Wyniki wskazały, że lepkość zawiesiny bentonit-PDDACl wzrasta nie tylko wraz ze wzrostem stężenia polimeru, ale także ze wzrostem udziału fazy stałej. Adsorpcja polimeru PDDACl zwiększa dodatniość powierzchni bentonitu w funkcji stężenia polimeru, co można tłumaczyć głównie oddziaływaniem elektrostatycznym deficytowych jonów metali na oktaedrycznych arkuszach bentonitu z kationową grupą polimeru. Izoterma adsorpcji PDDACl na bentonicie pasuje bardziej do izotermy Langmuira niż izotermy Freundlicha.

Słowa kluczowe: bentonit, glina, polimer kationowy, Poli(chlorek diallilodimetyloamoniowy), lepkość 